\title{
DNA analysis of Huntington's disease in southern Chinese
}

\author{
Vivian Chan, Y L Yu, T P T Chan, B Yip, C M Chang, M T H Wong, Y W Chan, \\ T K Chan
}

\begin{abstract}
Allelic frequencies of RFLPs at loci closely linked to the HD gene, D4S95, D4S91, D4S141, and D4S90, were determined in 13 Huntington's disease (HD) patients from nine Chinese families and 129 normal subjects. These were similar for non-HD and HD chromosomes and the HD gene in Chinese is associated with multiple haplotypes. Hence the HD gene probably arose independently in the background haplotypes of the Chinese population. The heterozygosity rates for the two most useful RFLP sites are 0.659 for D4S95-AccI VNTR and 0.494 for D4S141-HindIII.
\end{abstract}

(CAG)n repeat numbers ranged from 12 to 27 in 174 normal chromosomes. In 52 meiotic recombinations, the (CAG)n repeats were stably inherited in normal families. In HD families, 12 of 13 HD patients had expanded (CAG)n repeats of 40 to 58. Additionally, 10 asymptomatic family members had expanded (CAG)n repeats and the inheritance of the expanded repeat was unstable in these families.

University

Department of

Medicine, Queen Mary

Hospital, Hong Kong

V Chan

Y L Yu

T P T Chan

B Yip

T K Chan

Department of Medicine, Ruttonjee Hospital, Hong Kong

C M Chang

University

Department of

Psychiatry, Queen

Mary Hospital,

Hong Kong

M T H Wong

Department of

Medicine, Kwong Wah

Hospital, Kowloon,

Hong Kong

Y W Chan

Correspondence to: Professor V Chan.

Received 16 April 1994 Revised version
accepted for publication 12 September 1994
(F Med Genet 1995;32:120-124)

Huntington's disease (HD) is an inherited neurodegenerative disorder manifesting usually in middle life and presenting with involuntary choreic movements, cognitive and psychiatric disturbances, and dementia. ${ }^{1}$ There is currently no effective treatment nor means to delay the inexorable progression to death which occurs some 10 to 20 years after the onset of disease. The disease is transmitted in an autosomal dominant manner; although the frequency of new mutation is low, ${ }^{2}$ the high degree of penetrance results in large numbers of affected persons within an HD family.

Until recently, various DNA markers from chromosome $4 \mathrm{p} 16.3$ have been used in linkage studies of the gene $e^{3-5}$ and in some cases it was possible to offer predictive testing based on RFLP linkage analysis. The identification of the HD gene (IT 15) and detection at the $5^{\prime}$ end of a trinucleotide repeat sequence (CAG) which is expanded in $\mathrm{HD}^{6}$ have allowed more Most analyses have been performed on white accurate molecular diagnosis of the condition.
European and American families. ${ }^{78}$ The frequency of HD among Japanese is low and linkage analysis supports the view that the gene for Japanese HD may be identical to the western gene. ${ }^{9}$ In Hong Kong, where the population is over $95 \%$ ethnic southern Chinese, the incidence of HD is low. ${ }^{10}$ Previous experience with other genetic diseases, such as $\beta$ thalassaemia and haemophilia $A$ and $B$, has shown that the mutations and RFLP heterozygosity rates vary for different ethnic groups. ${ }^{11-13} \mathrm{We}$ studied allelic frequencies of the various HD DNA markers and analysed trinucleotide repeats in both HD and normal chromosomes in the local Chinese population in an attempt to define the molecular defect in Chinese HD.

\section{Materials and methods}

DNA was obtained from nine unrelated HD families consisting of 13 clinically diagnosed HD patients (age of onset ranging from 20 to 70 years) and 36 of their family members. Family members were counselled by a team which included a neurologist, a molecular geneticist, and a psychiatrist. Informed consent was obtained from all the subjects and each was aware of the test being undertaken. DNA samples from $20 \beta$ thalassaemia families comprising father, mother, and one child, a haemophilia A family with nine members from three generations, and an additional 30 normal males and 30 normal females (aged 20 to 50 years) were used as controls. All subjects were southern Chinese living in Hong Kong, they or their ancestors being migrants from Guangdong province of South China. Nine unrelated HD chromosomes and 174 unrelated normal chromosomes were available for analysis.

DNA was extracted from peripheral blood leucocytes of each subject. For RFLP analysis, $5 \mu \mathrm{g}$ amounts were digested with either $A c c \mathrm{I}$, MboI, PstI, TaqI, MspI, HindIII, or PvuII under conditions recommended by the manufacturer (New England Biolabs, Mass, USA). The digested DNA fragments were electrophoresed in $0 \cdot 8 \%$ agarose, transferred onto a nitrocellulose filter, and hybridised with ${ }^{32} \mathrm{P}$ labelled gene probes, using standard techniques. ${ }^{14}$ The hybridised filters were washed under stringent conditions and autoradiographed for two to 
Table 1 Allele frequencies for RFLPs on non-HD and HD chromosomes

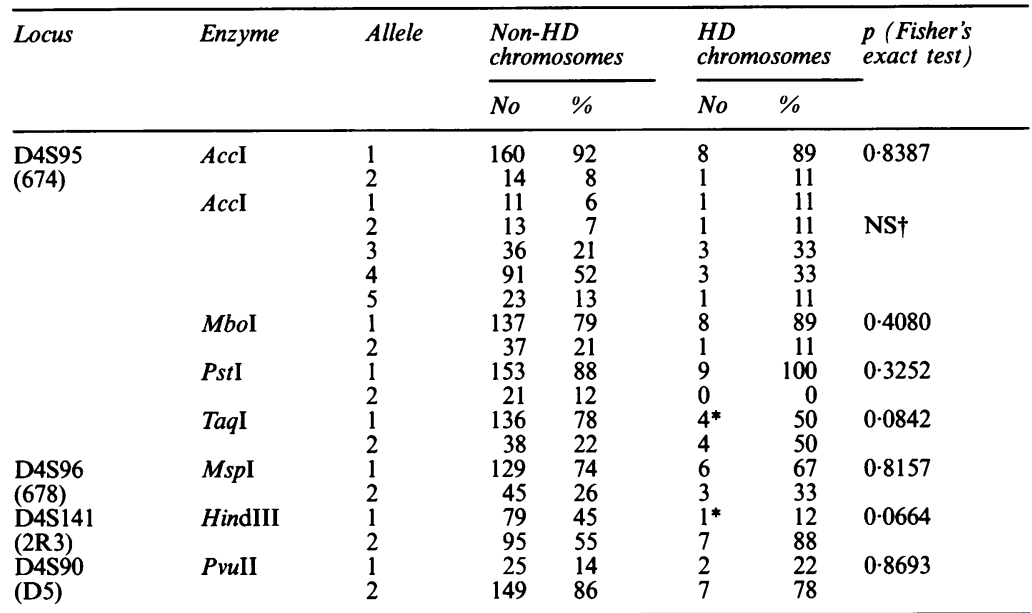

* One HD patient was excluded from the analysis. He was heterozygous for the site and having no other family member available for study, it was not possible to assign his haplotype. $+\chi^{2}=1 \cdot 7176, \mathrm{df}=4, \mathrm{p}=0 \cdot 7875$.

five days. The RPLP sites and probes used were $A c c \mathrm{I}, M b o \mathrm{I}, P s t \mathrm{I}$, and TaqI detected by probe $674(1.0 \mathrm{~kb} E c o$ RI insert) in the D4S95 region, ${ }^{4} M s p$ I detected by probe 678 (a $0.9 \mathrm{~kb}$ EcoRI insert) in D4S $96,{ }^{15}$ HindIII detected by probe $2 \mathrm{R} 3$ in D4S141, ${ }^{16}$ and PvuII hybridised to probe D5 which is a $1.8 \mathrm{~kb} E c o \mathrm{RI}$ insert in the D4S90 region. $^{17}$

AMPLIFICATION OF (CAG)n REPEAT

Genomic primers (HDA and HDB as $5^{\prime}$ and $3^{\prime}$ primers respectively) flanking the trinucleotide repeat sequence were synthesised as described by the Huntington's Disease Collaborative Research Group (1993). ${ }^{6}$ This PCR product should include the CAG repeats and the adjacent CCG and CCN repeats between nucleotide (nt) 316-584 of the published sequence. ${ }^{6}$ Polymerase chain reaction (PCR) amplification was performed in a $25 \mu \mathrm{l}$ reaction volume containing $50 \mathrm{ng}$ genomic DNA, $200 \mathrm{mmol} / 1$ (each) $\mathrm{dNTP}, 50 \mathrm{ng}$ of ${ }^{32} \mathrm{P}$ end labelled $5^{\prime}$ primer, $250 \mathrm{ng}$ of unlabelled $5^{\prime}$ primer, $300 \mathrm{ng}$ of unlabelled $3^{\prime}$ primer, $1 \mathrm{U}$ Taq Polymerase (Perkin Elmer Cetus), 10\% dimethyl sulphoxide, and enzyme buffer as recommended by the manufacturer. After denaturation at $94^{\circ} \mathrm{C}$ for five minutes, the cycling conditions for 40 cycles were one minute at $94^{\circ} \mathrm{C}$, one minute at $60^{\circ} \mathrm{C}$, and two minutes extension time at $72^{\circ} \mathrm{C}$. A $5 \mu \mathrm{l}$ aliquot of the PCR product was diluted with an equal volume of $95 \%$ formamide loading dye and denatured at $95^{\circ} \mathrm{C}$ for two minutes before analysis on $8 \mathrm{~mol} / 1$ urea and $6.5 \%$ acrylamide gel $(60 \mathrm{~cm})$ at $20 \mathrm{~mA}$. A single stranded M13 was sequenced and analysed in the same gel as standard.

Two other sets of PCR primers were synthesised; HD3 and HD482 according to the sequences published by Kremer et al. ${ }^{18}$ When HD3 and HD482 were used, the PCR product included the (CAG)n as well as the immediately adjacent set of (CCG)n, between nt 344-482 of the published sequence. ${ }^{6}$ PCR cycling conditions were $94^{\circ} \mathrm{C}$ for one minute, $64^{\circ} \mathrm{C}$ for one minute, $72^{\circ} \mathrm{C}$ for two minutes, for 35 cycles. The third $3^{\prime}$ primer used was HD4V, spanning nt 446-431, and when used with HD3 as $5^{\prime}$ primer, the PCR product would only contain the (CAG)n. PCR cycling conditions were $94^{\circ} \mathrm{C}$ for one minute, $60^{\circ} \mathrm{C}$ for one minute, and $72^{\circ} \mathrm{C}$ for two minutes for 35 cycles.

PCR for the trinucleotide repeat associated with dentatorubral and pallidoluysian atrophy (DRPLA) was performed in one HD family, using primers and conditions as described by Nagafuchi et al. ${ }^{19}$

\section{Results}

RFLP ANALYSIS

The allelic frequencies for the various RFLPs on non-HD (normal) and HD chromosomes are given in table 1. There was no significant difference in allele frequencies between the two groups. Calculation of heterozygosity rate was based on data from the normal chromosomes (table 2). Apart from the highly polymorphic variable number tandem repeats (VNTR) at the AccI site, the HindIII site in D4S141 would appear the most useful with a heterozygosity rate of 0.494

On comparing the allelic frequencies of the RFLPs in different ethnic groups (table 3), significant differences were observed in each except for D4S95-PstI, D4S96-MspI, and D4S141-HindIII sites. With the D4S95-TaqI site, the allelic frequency in the Chinese was the reverse of that found in white $e^{41517}$ and

Table 2 The heterozygosity rate of various RFLPs linked to the HD gene in the Chinese population

\begin{tabular}{|c|c|c|c|c|c|c|}
\hline \multirow[t]{2}{*}{ Locus (probe) } & \multirow[t]{2}{*}{ Restriction site } & \multicolumn{2}{|l|}{ Frequency } & \multicolumn{2}{|c|}{ Heterozygosity rate $(H)$} & \multirow{2}{*}{$\frac{\chi^{2}}{p}$} \\
\hline & & $\begin{array}{l}\text { Allele } 1 \\
(p)\end{array}$ & $\begin{array}{l}\text { Allele } 2 \\
(q)\end{array}$ & Observed & Expected (pq) & \\
\hline \multirow{3}{*}{$\begin{array}{l}\text { D4S95 } \\
(674)\end{array}$} & $A c c \mathrm{I}$ & 0.919 & 0.080 & $0 \cdot 142$ & $0 \cdot 147$ & NS $†$ \\
\hline & AccI (VNTR) & $\begin{array}{l}\text { (1) } 0.063 \\
\text { (2) } 0.074 \\
\text { (3) } 0.207\end{array}$ & $\left.\begin{array}{l}\text { (4) } 0.522 \\
\text { (5) } 0.132\end{array}\right\}$ & $0 \cdot 214$ & $0 \cdot 659^{*}$ & $0.0000 \ddagger$ \\
\hline & $\begin{array}{l}\text { MboI } \\
\text { PstI } \\
\text { TaqI }\end{array}$ & $\begin{array}{l}0.787 \\
0.877 \\
0.781\end{array}$ & $\begin{array}{l}0.212 \\
0 \cdot 122 \\
0.218\end{array}$ & $\begin{array}{l}0.342 \\
0.231 \\
0.314\end{array}$ & $\begin{array}{l}0.333 \\
0.213 \\
0.340\end{array}$ & $\begin{array}{l}\text { NS } \\
\text { NS } \\
\text { NS }\end{array}$ \\
\hline $\begin{array}{l}\text { D4S96 } \\
(678)\end{array}$ & $M s p \mathrm{I}$ & 0.741 & $0 \cdot 258$ & 0.157 & 0.382 & $0.0028 \ddagger$ \\
\hline $\begin{array}{l}\text { D4S141 } \\
\text { (2R3) }\end{array}$ & HindIII & 0.454 & 0.545 & 0.457 & 0.494 & NS \\
\hline $\begin{array}{l}\text { D4S90 } \\
\text { (D5) }\end{array}$ & PvuII & $0 \cdot 143$ & $0 \cdot 856$ & $0 \cdot 185$ & $0 \cdot 244$ & NS \\
\hline
\end{tabular}

* Calculated by polynomial equation for multiple alleles, where: $H=1-\left(p^{2}+q^{2}+r^{2} \ldots\right)$.

$\dagger$ NS = not significant

$\ddagger$ Significant difference between observed and expected heterozygosity rates is because of more people being homozygous for one allele. 
Table 3 Allelic frequencies of various RFLPs linked to the HD gene in different ethnic groups

\begin{tabular}{|c|c|c|c|c|c|c|c|c|c|c|}
\hline \multirow{2}{*}{$\begin{array}{l}\text { Locus } \\
\text { (probe) }\end{array}$} & \multirow{2}{*}{$\begin{array}{l}\text { Restriction } \\
\text { enzyme }\end{array}$} & \multirow[t]{2}{*}{ Allele } & \multirow[t]{2}{*}{ Size $(k b)$} & \multicolumn{4}{|c|}{ Frequency (No studied) } & \multirow[t]{2}{*}{$x^{2}$} & \multirow[t]{2}{*}{$d f$} & \multirow[t]{2}{*}{$p$} \\
\hline & & & & Chinese* & White $\dagger$ & $U K \ddagger$ & Italian§ & & & \\
\hline \multirow[t]{10}{*}{$\begin{array}{l}\text { D4S95 } \\
(674)\end{array}$} & $A c c \mathrm{I}$ & $\begin{array}{l}1 \\
2\end{array}$ & $\begin{array}{l}7 \cdot 0 \\
1.5\end{array}$ & $\begin{array}{l}0.919(174) \\
0.080\end{array}$ & $\begin{array}{l}0.70(100) \\
0.30\end{array}$ & $\begin{array}{l}0.58(99) \\
0.42\end{array}$ & - & $45 \cdot 1$ & 2 & 0.0000 \\
\hline & $A c c \mathrm{I}$ & 1 & $4 \cdot 5$ & $0.063(174)$ & $0.07(100)$ & - & $0.03(94)$ & $47 \cdot 4$ & 8 & 0.0000 \\
\hline & & 2 & $4 \cdot 4$ & 0.074 & 0.23 & & 0.14 & & & \\
\hline & & 3 & $4 \cdot 3$ & 0.207 & $0 \cdot 10$ & & 0.04 & & & \\
\hline & & 4 & $4 \cdot 2$ & 0.522 & 0.50 & & 0.78 & & & \\
\hline & & 5 & $4 \cdot 1$ & $0 \cdot 132$ & $0 \cdot 10$ & & 0.00 & & & \\
\hline & Mbol & 1 & $1 \cdot 2$ & $0.787(174)$ & $0 \cdot 65(100)$ & $0.63(90)$ & - & $9 \cdot 4$ & 2 & $0 \cdot 0090$ \\
\hline & Pst $\mathbf{I}$ & $\begin{array}{l}2 \\
1\end{array}$ & $\begin{array}{l}0 \cdot 7 / 0 \cdot 5 \\
8 \cdot 6\end{array}$ & $\begin{array}{l}0 \cdot 212 \\
0.877(172)\end{array}$ & $\begin{array}{l}0.35 \\
0.91(100)\end{array}$ & $\begin{array}{l}0.37 \\
0.93(110)\end{array}$ & & 1.9 & 2 & 0.3750 \\
\hline & & 2 & 1.7 & $0 \cdot 122$ & 0.09 & 0.07 & & 19 & 2 & טאוכ50 \\
\hline & TaqI & 1 & $\begin{array}{l}2 \cdot 3 \\
1.7\end{array}$ & $\begin{array}{l}0.781(174) \\
0.218\end{array}$ & $0.38(100)$ & $0 \cdot 51(49)$ & $0 \cdot 32(82)$ & $67 \cdot 7$ & 3 & 0.0000 \\
\hline D4S96 & MspI & 1 & $1 \cdot 3$ & $\begin{array}{l}0.218 \\
0.741(174)\end{array}$ & $\begin{array}{l}0.62 \\
0.5(12)\end{array}$ & $\begin{array}{l}0.49 \\
-\end{array}$ & 0.68 & $3 \cdot 28$ & 1 & 0.0698 \\
\hline (678) & & 2 & 1.0 & 0.258 & 0.5 & & & & & \\
\hline D4S 141 & HindIII & 1 & $5 \cdot 6$ & $0.454(174)$ & - & $0 \cdot 36(60)$ & - & $1 \cdot 38$ & 1 & 0.2388 \\
\hline (2R3) & & 2 & 3.9 & 0.545 & & 0.64 & & & & \\
\hline D4S9́0 & PvuII & 1 & $5 \cdot 6$ & $0 \cdot 143(174)$ & $0 \cdot 14(76)$ & $0.90(96)$ & - & $171 \cdot 7$ & 2 & 0.0000 \\
\hline (D5) & & 2 & $5 \cdot 0$ & 0.856 & 0.86 & $0 \cdot 10$ & & & & \\
\hline
\end{tabular}

* Chan et al: present study, 1994.

† Wasmuth et al ${ }^{4}$; Youngman et al ${ }^{17}$; Smith et al. ${ }^{15}$

† Snell et al.

$\S$ Frontali et al. ${ }^{20}$

Italian $^{20}$ populations, while a separate report from the United Kingdom showed approximately equal numbers of both alleles. With the D4S90-PvuII site, the frequencies of alleles 1 and 2 in both Chinese and whites were the reverse of those in the people from the UK. ${ }^{5}$

TRINUCLEOTIDE REPEAT ASSAY

Trinucleotide repeat assays were performed using all three sets of PCR primers. Thus it was possible to calculate the (CAG)n, (CCG)n, and $(\mathrm{CCN}) \mathrm{n}$ in each sample. The CCG and $\mathrm{CCN}$ repeats were not as polymorphic as the CAG repeats, with a range of 5 to 11 repeats for CCG and 6 to 12 repeats for CCN respectively in the 174 normal chromosomes studied and they were not expanded in the HD

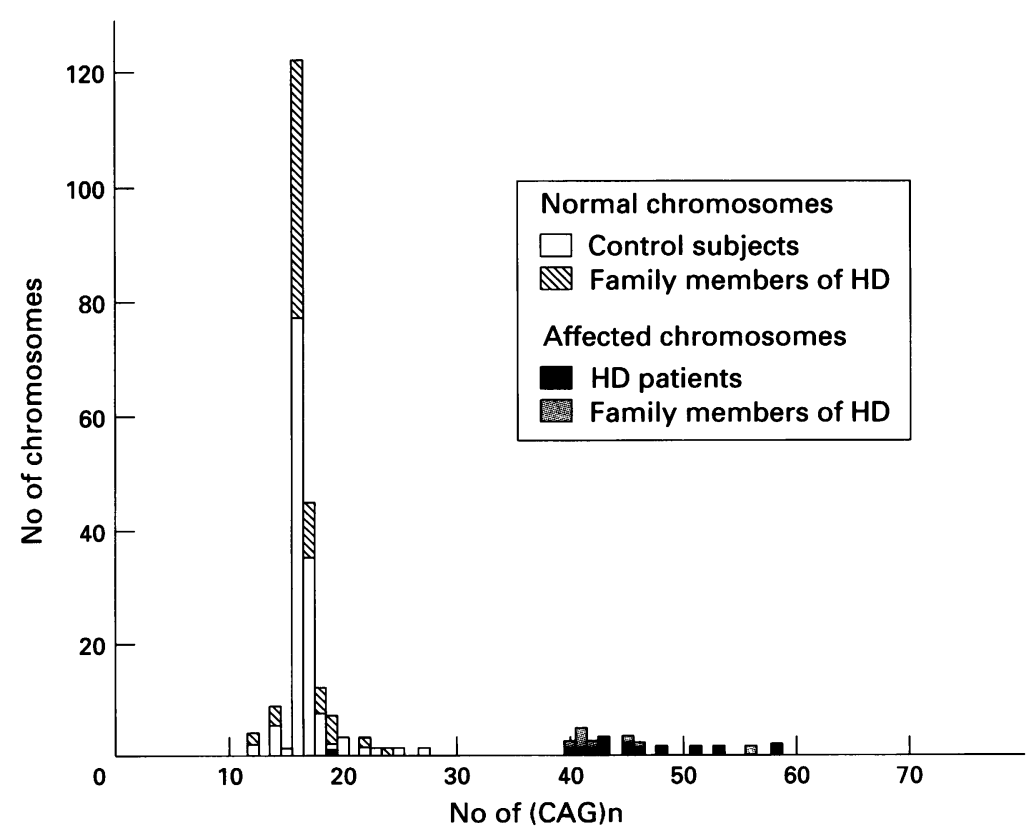

Figure 1 Histogram showing distribution of CAG repeats on the normal chromosomes of control subjects and family members of $H D$ patients, as well as on affected chromosomes of HD patients and asymptomatic family members of these patients with expanded repeats. chromosomes (CCG repeats ranged from 6 to $10, \mathrm{CCN}$ repeats 7 to 13$)$.

(CAG)n REPEAT (USING PRIMERS HD3 AND HD4V)

In 174 normal chromosomes, (CAG)n repeats ranged from 12 to 27 (mean 16.718, SD 1.910 ). There was no significant difference between males and females (males mean 16.682 , SD 2.001 and females mean 16.753 , SD 1.830). Values for the affected chromosome in 12 of the 13 clinically diagnosed HD patients ranged from 40 to 58 repeats. In one $\mathrm{HD}$ patient, no expanded (CAG)n repeat was observed in four PCR assays. Ten asymptomatic family members were found to have expanded trinucleotide repeats. The distribution of CAG repeats on different chromosomes is shown in fig 1.

In two families, the expanded trinucleotide repeat was inherited by all the sibs, although at the time of study, only the oldest one or two of the sibs had manifested the disease. Fig 2 shows the results of trinucleotide repeat assay in one family. DNA haplotype analysis in this family was also consistent with the conclusion that all sibs carry the abnormal chromosome.

In one family, (CAG)n assay on four different occasions showed that the HD patient had repeats of only 17 . These same size repeats were found in one of his two asymptomatic sibs, who, on haplotype analysis, had inherited the same "affected" chromosome as the patient from their dead father, who was affected. The mother who is normal had two alleles of 16 and 17 (CAG)n repeats while the other sister had 16 and 19 (CAG)n repeats. Trinucleotide repeat assay associated with the DRPLA gene showed normal sized repeats for this patient as well as for all his family members.

(CAG)n ANALYSIS IN NORMAL FAMILIES

Determination of the size of trinucleotide repeat in $20 \beta$ thalassaemia families as well as the three generations of a haemophilia A family showed that in all 26 offspring (that is, 52 


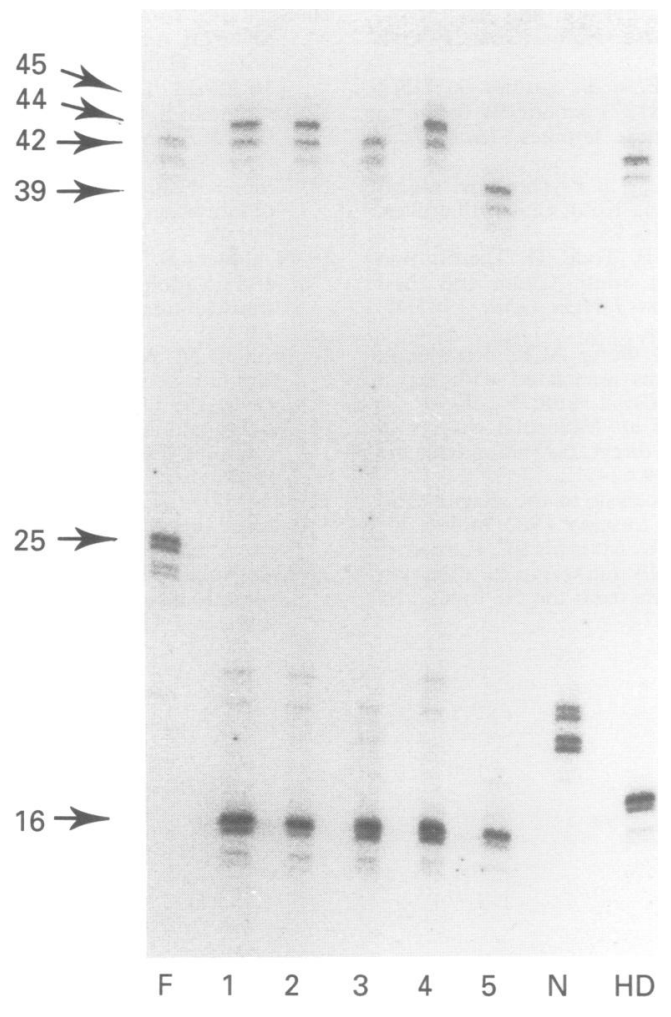

Figure 2 Trinucleotide repeats in an HD family. The father $(F)$ and one of his children (2) are affected. The other asymptomatic children $(1,3,4,5)$ also had expanded trinucleotide repeats. Normal subject $(N)$ and one other patient (HD) were assayed as negative and positive controls. Arrowed numbers indicate repeat sizes of the family.

meiotic recombinations), the (CAG)n repeat lengths were stably inherited from both the paternal and maternal normal genes.

\section{Discussion}

The reported incidence of HD in the local Chinese population is low, possibly because within the Chinese culture there is a strong sense of denial of such debilitating disorders, especially when there is no cure. However, with more accurate molecular analysis of the HD gene using trinucleotide repeat assay, predictive testing and prenatal diagnosis could become available and this could have a more positive effect on bringing forth the HD families. In anticipation of the predictive testing service, we studied the (CAG)n repeat of the HD gene in both affected and normal chromosomes and compared this method to RFLP analysis using the various linked DNA markers.

Like previous experiences with $\beta$ thalassaemia and haemophilia $A$ and $B$, the heterozygosity rates for the various RFLP sites in Chinese are different from ethnic groups in the West, most notably the $A c c$ I site in the D4S95 region, the TaqI site in D4S95, and the PvuII site in D4S90. With the latter two RFLP sites, the allele frequencies are the reverse of those found in the other ethinic groups. This underlines the importance of determining the heterozygosity rate for a particular population before deciding on the most suitable site for use in linkage analysis. For southern Chinese, the most useful sites are the D4S95- $A c c$ I VNTR and the D4S141-HindIII site (table 2). In agreement with previous findings of $\mathrm{HD}$ in European populations, ${ }^{21}$ we have also observed multiple HD haplotypes, even within the small number of patients studied, providing support for the multiple independent origin of mutations causing HD. There was no difference in the allele frequencies of various RFLPs on the normal and the HD chromosomes (table 1).

Trinucleotide repeat of the HD gene in Chinese is similar to that reported for white populations. ${ }^{7822}$ There was no overlap in repeat size between the normal group and the affected, possibly because of the relatively small number of clinically diagnosed patients. No potential parental source effect was noted in this group of HD patients and, again, this may be ascribed to the small number studied. The unstable inheritance of the (CAG)n repeat was only observed in HD chromosomes and not in the control group of thalassaemic or haemophiliac families. It is therefore likely that expansion of (CAG)n repeat number in family members is predictive of future disease.

The reason for the absence of the expanded trinucleotide repeat in one HD patient remains unknown. The patient had unfortunately died and as his family refused necropsy, no other sample of blood or brain was available. However, as somatic mosaicism of the expanded $\mathrm{HD}$ repeat is thought to be rare, ${ }^{23}$ it is unlikely that a brain sample would give a different result from the peripheral blood DNA. CT scanning of this patient showed caudate atrophy and he had psychiatric and cognitive involvement, with typical chorea. His cause of death was pneumonia. DNA haplotyping of this patient and his sister showed they have inherited the same "affected" chromosome, although the sister was still asymptomatic at the time of study. Both the patient and his sister had normal sized (CAG)n repeats associated with the DRPLA gene. It is unlikely that he was suffering from DRPLA. This may represent a different genetic defect for a subgroup of HD patients or that the trinucleotide expansion may only occur in brain tissue. Hence genetic counselling for such a family is not possible at present.

We are grateful to Dr J J Wasmuth, Dr D Shaw, and Professor P S Harper for generous supply of the DNA probes, and the Croucher Foundation for research support.

1 Martin JB, Gusella JF. Huntington's disease: pathogenesis and management. $N$ Engl $\mathcal{F}$ Med 1986;315:1267-76.

2 Harper PS. Genetic aspects of Huntington's disease. In: Harper PS, ed. Huntington's disease. Major Problems in Neurology Vol 22. London: Saunders, 1991:281-315.

3 Gusella JF, Wexler NS, Conneally PM, et al. A polymorphic DNA marker genetically linked to Huntington's disease. Nature 1983;306:234-8

4 Wasmuth JJ, Hewitt J, Smith B, et al. A highly polymorphic locus very tightly linked to the Huntington's disease gene. Nature 1988;332:734-6. 5 Snell RG, Lazarou L, Youngman S, et al. Linkage disequilibrium in Huntington's disease: an improved
alisation of the genes. $\mathcal{Y}$ Med Genet 1989;26:673-5.

6 Huntington's Disease Collaborative Research Group. A novel gene containing a trinucleotide repeat that is exnovel gene containing a trinucleotide repeat that is ex-
panded and unstable on Huntington's disease chro-
mosomes. Cell 1993;72:971-83.

7 Duyao M, Ambrose C, Myers R, et al. Trinucleotide repeat length instability and age of onset in Huntington's disease.
lose Nature Genet 1993;4:387-92.

8 Snell RG, MacMillan JC, Cheadle JP, et al. Relationship 
between trinucleotide repeat expansion and phenotypic variation in Huntington's disease. Nature Genet 1993;4: 393-7.

9 Kanazawa I, Kondo I, Ikeda JE, et al. Studies on DNA markers (D4S10 and D4S43/S127) genetically linked to Huntington's disease in Japanese families. Hum Genet 1990;85:257-60.

10 Wong MTH, Chang PCM, Yu YL, et al. Psychosocial impact of Huntington's disease on Hong Kong Chinese families. Acta Psychiatr Scand 1994;90:16-18.

11 Chan V, Chan TK, Chebab FF, Todd D. Distribution of $\beta$-thalassemia mutations in South China and their association with haplotype. Am $\Im$ Hum Genet 1987;41: 678-85.

12 Chan V, Chan TK, Liu VWS, Wong ACK. Restriction fragment length polymorphisms associated with factor fragment length polymorphisms associated with factor

13 Chan V, Yip B, Tong TMF, et al. Molecular defects in haemophilia B: detection by direct restriction enzyme analysis. $\mathrm{Br}$ f Haematol 1991;79:63-9.

14 Goossens M, Kan YW. DNA analysis in the diagnosis of hemoglobin disorders. Methods Enzymol 1981;76:805-17.

15 Smith B, Skarecky D, Bengtsson U, Magenis RE, Carpenter $\mathrm{N}$, Wasmuth JJ. Isolation of DNA markers in the direction of the Huntington's disease gene from the G8 locus. $\mathrm{Am}$ f Hum Genet 1988;42:335-44.
16 Snell RG, Youngman S, Lehrach H, Sarfarazi M, Harper PS, Shaw DJ. A new probe (2R3) in the region of Huntington's disease. Human Gene Mapping. Cytogenet Cell Genet 1989; 10:A2621

17 Youngman S, Shaw DJ, Gusella JF, et al. A DNA probe D5 (D4S90) mapping to human chromosome 4p16.3. Nucleic Acids Res 1988;16:1648.

18 Kremer B, Squitieri F, Telenius $\mathrm{H}$, et al. Molecular analysis of late onset Huntington's disease. F Med Genet 1993;30: 991-5.

19 Nagafuchi S, Yanagisawa $H$, Sato $K$, et al. Dentatorubral and pallidoluysian atrophy expansion of an unstable CAG trinucleotide on chromosome 12p. Nature Genet 1994;6: 14-18.

20 Frontali M, Malaspina P, Rossi C, et al. Epidemiological and linkage studies on Huntington's disease in Italy. Hum 85:165-70.

21 MacDonald ME, Novelletto A, Lin C, et al. The Huntington's disease candidate gene exhibits many different

22 MacMillan JC, Snell RG, Tyler A, et al. Molecular analysis and clinical correlations of the Huntington's disease mutation. Lancet 1993;342:954-8.

23 MacDonald ME, Barnes G, Srinidhi J, et al. Gametic but not somatic instability of CAG repeat length in Huntington's disease. F Med Genet 1993;30:982-6. 